\title{
Review of \\ Malachi Edwin Vethamani, Coitus Interruptus and Other Stories
}

Luis Ortega

Nottingham University Malaysia, Selangor, Malaysia

SARE: Southeast Asian Review of English, Vol. 55, Issue 1, 2018 


\section{SARE, Vol. 55, Issue 1 | 2018}

\section{Malachi Edwin Vethamani. Coitus Interruptus and Other Stories. Kuala Lumpur: Maya Press, 2018. pp. 92. ISBN 9789832737568.}

$\mathbf{W}_{\mathrm{h}}$

hen French composer Maurice Ravel offered his piano concerto in G Major to pianist Marguerite Long to perform, she praised the opening melody for its effortless and natural flow. Ravel is said to have retorted: "Ah, the phrase flows, you say? Well, it so happens that I worked at it endlessly. It nearly killed me!". The twelve stories in Malachi Edwin Vethamani's first collection of short fiction, Coitus Interruptus, seem to flow equally effortlessly, almost as if they had been created in one sitting. As in the case of Hemingway, mastery of the art of storytelling usually comes with the semblance of ease, allowing readers to forget a writer was ever there, permitting them to enter directly into the characters' lives. The simplicity and directness of the stories that make up Coitus Interruptus, as the careful reader realises, are in fact the result of years of craftsmanship and the author's belief in the power of literature to speak to us and move us deeply.

Vethamani's characters are often, although not exclusively, Malaysian Indians dealing with matters of personal freedom and choice. Difficulties arise, as it is often the case in all human communities, when societal expectations come into conflict with expressions of the self.

Sunitha, the main character of the story that gives the collection its title, is a modern liberated Tamil woman surrounded by girlfriends who initially cannot understand her choice of living her life on her own terms. These women, who have mostly adapted to their roles as housewives with gusto, teasingly push Sunitha towards the fate they themselves have embraced and believe that all young, middle-class Indian women should fulfill: Getting Married. Soon. Otherwise, their words voice the subconscious mantra of patriarchy, "No man will want to marry you". It is the quieter of her friends, Zaitun, disappointed that her own marriage is ending in divorce and empowered by her new understanding of the pressures of social conformity, who supports Sunitha's choice to move towards independence. The story ends in the form of a coitus interruptus, a theme that permeates the story on many levels. We, as readers, however, sense the full resolve of the young protagonist to survive despite all odds. Shanti, the protagonist of "Husband Material" is another freethinking girl, who, against the advice of her uncle, embarks on a relationship of youthful love, only to find her aspirations and desires frustrated by the institution of arranged marriage and her lover's conformity.

Many of Vethamani's characters, including Sunitha of the titular story, try to escape the traps that societal mores impose on their freedom by putting geographical distance between themselves and the older generation's expectations. Thus, in "The Good Story", Ravi, like his sister Prema Akka in "The Good Daughter", find refuge in Europe. Away from home, they are able to carve out a place for the exploration of their innermost desires and longings. In "Beaten Twice", Jack and Darren explore their carnal desires in Italy, but their Malaysian identities keep intervening.

Vethamani, however, does not only portray women and their joys and sorrows. His characters also include men who face their own personal struggles against society's dictates. In "The Dastardly Twin", Paul confronts his internalised ageism, propelled by his perceived loss of his youthful looks. Like a reverse Dorian Gray, his fixed inner image of himself, fuelled by our age's obsession with youth and beauty, refuses to let him find comfort in change and growth. 


\section{SARE, Vol. 55, Issue $1 \mid 2018$}

Some of Vethamani's most memorable male characters are gay men who have to navigate their lives in a society in which homosexuality remains taboo. But not for Vethamani the indignant rage of a Larry Kramer, or indeed any form of apology. He offers these vignettes of Malaysian life just as their characters might inhabit them, with candour and directness. "The Interloper," a piece of flash fiction, shows us the dangers lurking within a ménage à trois, at least for the third party. Other stories, such as "Callas and a Piece of Blue Cloth" and "Best Man's Kiss," revolve around the loss of loved ones to conventional or heterosexual marriage, including men who are not daring enough to remain in unrecognised relationships with their same-sex partners and elect to follow the path set by their elders. It is to Vethamani's credit that the rejected lovers are depicted in their full humanity. The non-judgmental authorial voice is also understanding and forgiving of the runaway lovers' decisions.

"In Close Proximity" is a story of interracial and inter-faith love and its possible consequences. It opens with an episode of childhood memories reminiscent of Proust's $\grave{A}$ la Recherche $d u$ Temps Perdu, set against the background of one of the darkest chapters in Malaysian history — the riots of 13 May 1969. "The Kiss" is a family tale that won the Consolation Prize in the National Short Story Competition organised by Shell and NST in 1995. "Ghosts" closes the collection with the motifs of familial duty and the gift of friendship. Set in the near future, it almost absent-mindedly poses questions of the type that only speculative fiction can: What will become of interracial relations in Malaysia? Will the country remain a poster society for Islamic moderation? The story's ending ties the personal with the communal, offering the reader a deeply satisfying sense of closure.

Ultimately, the stories in Coitus Interruptus transcend locality, and in so doing achieve universal significance. Characters, however sketchy some of them may appear at first reading, stay with us, as fully realized human beings. To create such memorable characters in such a concise format as the short story is no small feat. Despite the generational, social, and gender clashes they are faced with, the characters who populate Vethamani's collection come out of their various struggles triumphant - quietly accepting the outer limitations to their inner longings, but fully resolved to carving out a meaningful life within those boundaries. 